\title{
SPATIAL AND TEMPORAL VARIABILITY OF EH AND PH OVER A RICE FIELD AS RELATED TO LIME ADDITION ( $\left.{ }^{(}\right)$
}

\author{
LUIS ALBERTO MORALES $\left(\left(^{*}\right)\right.$; JORGE PAZ-FERREIRO $\left({ }^{3}\right)$; SIDNEY ROSA VIEIRA $\left({ }^{4}\right)$; \\ EVA VIDAL VÁZQUEZ ( $\left.{ }^{3}\right)$
}

\begin{abstract}
The aim of this study was to describe the effect of lime additions on the spatial variability of $\mathrm{pH}$ and Eh in a typic Plintacualf cultivated with rice, in Corrientes, Argentina. The 5.1 ha field was divided in three sub plots at which dolomitic lime additions were made at the rates zero, $625 \mathrm{~kg} \mathrm{ha}^{-1}$ and $1250 \mathrm{~kg} \mathrm{ha}^{-1}$. The soil was sampled at three stages: before sowing thus in aerobic conditions, and then two more times in anaerobiosis. Ninety-six samples per sub plot were taken on each of the three sampling stages on a grid of $11.9 \times 20 \mathrm{~m}$. Soil $\mathrm{pH}$ and Eh were measured by routine methods. The $\mathrm{pH}$ values increased, whereas Eh values decreased, following flooding. The coefficients of variation for $\mathrm{pH}$ was rather low during all the three studied periods. Conversely, the CV values for Eh were initially low but with a sharp increased in the second sampling date. The spatial variability of the studied soil properties was assessed using semivariogram analysis and examination of the maps constructed with values interpolated with kriging. Soil $\mathrm{pH}$ exhibited a rather strong spatial dependence, whereas soil Eh had a strong to moderate spatial dependence all over the three studied periods and for the three lime rates. Spherical models reaching a stable sill with low to moderate nugget effect were fitted to the experimental semivariograms for the 18 data sets (3 subplots, 3 liming rates and 2 properties) studied. Spatial variability of $\mathrm{pH}$ and Eh on rice fields was far from negligible both on aerobic and on anaerobic conditions. In general $\mathrm{pH}$ exhibited a stronger spatial dependence than Eh and also showed a tendency to present smaller ranges of spatial dependence. Contour maps clearly showed the presence of small scale variability for $\mathrm{pH}$ and Eh within each liming treatment and during each of the three sampling dates. Neither $\mathrm{pH}$ or Eh had temporal stability of the pattern of spatial distribution on field studied.
\end{abstract}

Key Words: semivariogram, flooded field, liming, kriging.

\section{RESUMO}

\section{VARIABILIDADE ESPACIAL E TEMPORAL DO PH E EH DO SOLO SOB CULTIVO DE ARROZ EM RELAÇÃO À ADIÇÃO DE CALCÁRIO}

\begin{abstract}
O objetivo deste trabalho foi descrever o efeito da adição do calcário na variabilidade espacial de $\mathrm{pH}$ e Eh, em um Typic Plintacualf cultivado com arroz, em Corrientes, Argentina. O campo de 5.1 ha foi dividido em três subparcelas onde foram efetuadas aplicações de calcário dolomitico nos níveis zero, $625 \mathrm{~kg} \mathrm{ha}^{-1}$ e 1250 $\mathrm{kg} \mathrm{ha}^{-1}$. Amostras de solo foram coletadas em três estágios: antes da semeadura (condição anaeróbica), e duas outras amostragens em condições anaeróbicas. Noventa e seis amostras por sub parcela foram coletadas em cada um dos três estágios em grade de 11.9 × $20 \mathrm{~m}$. O pH e o Eh do solo foram determinados nas amostras de solo pelos métodos de rotina. Os valores de $\mathrm{pH}$ aumentaram enquanto os de Eh diminuiram após a inundação. Os coeficientes de variação para $\mathrm{pH}$ foram muito baixos durante todos os três períodos estudados. Por outro lado, os CV para Eh foram inicialmente baixos mas tiveram aumento drástico a partir da segunda amostragem. A variabilidade espacial das propriedades do solo estudadas foi feita usando a análise de semivariogramas e o exame de mapas construídos com valores interpolados por krigagem. $\mathrm{O} \mathrm{pH}$ revelou dependência espacial forte enquanto o Eh, dependência entre forte e moderada, para os três períodos estudados e para os três tratamentos de calcário. Em todos os 18 casos estudados (trê subparcelas, três doses de calcário e duas propriedades) foram ajustados modelos esféricos aos semivariogramas experimentais, caracterizados por um patamar estável e um efeito pepita baixo ou moderado. A variabilidade espacial do $\mathrm{pH}$ e do Eh foi bastante grande tanto em
\end{abstract}

(1) Received for publication in September 12, 2008 and accepted in January $1^{\text {st }}, 2010$.

${ }^{(2) F a c u l t a d ~ d e ~ C i e n c i a s ~ A g r a r i a s . ~ U n i v e r s i d a d ~ N a c i o n a l ~ d e l ~ N o r d e s t e, ~ S a r g e n t o ~ C a b r a l, ~ 2131, ~ C o r r i e n t e s, ~ A r g e n t i n a . ~}$ E-mail: luiaber@yahoo.es $\left(^{*}\right)$ Corresponding author

${ }^{(3)}$ Facultad de Ciencias. Universidade da Coruña. Campus A Zapateira. C.P. 15071. A Coruña (Spain).E-mail: evidal@udc.es

( ${ }^{4}$ Instituto Agronômico (IAC), Avenida Barão de Itapura, 1481, 13020-902 Campinas (SP), Brasil. E-mail: sidney@iac.sp.gov.br 
condições aeróbicas como anaeróbicas. Em geral, o pH foi o depedente espacial mais forte do que Eh e com menores alcances de dependência espacial. Mapas de isolinhas claramente mostraram a presença de variabilidade em pequena escala dentro de cada tratamento de calagem nas três épocas de amostragem. Nem pH nem Eh mostraram estabilidade temporal da distribuição espacial nas condições estudadas.

Palavras-chave: semivariograma, arroz inundado, calagem, krigagem.

\section{INTRODUCTION}

Rice is an important economic and social crop in the northeast of Argentina. The main rice zones of this country are in the provinces of Corrientes and Entre Ríos, which accounts $85 \%$ of the domestic production. There is a minor contribution of neighboring areas in the Santa Fé, Chaco, Formosa and Misiones provinces (CARÑEL, 2008).

Soil spatial variability is a natural occurring and or management induced feature whose knowledge is important in order to choose adequate management practices. Since rice paddy fields are flooded and flat, apparently they should be homogeneous and, therefore, it has been thought that spatial variability in yields and soils might be negligible in fields having these characteristics. However, significant levels of variability in soil general properties, soil nutrients and rice yields (IIDA et al., 1999, YANAY et al., 2001; INAMURA et al., 2004, Roel and Plant, 2004)) have been observed even in small paddy fields (TRANGMAR et al., 1987). Moreover, soil properties ( $\mathrm{pH}$, organic mater, available $\mathrm{P}$ and $\mathrm{K}$ ) have been found to be spatially structured both under anaerobic rice crop and aerobic land uses (Sun et al., 2003).

A paddy field is a flooded parcel of arable land used for growing rice, a crop mainly cultivated in lowlands by semi aquatic conditions. Therefore, rice fields require large quantities of water for irrigation. Flooding provides water, essential in order to maintain the growth of lowland rice. Water also provides a favorable environment for the rice strains being grown as well as discouraging the growth of many weed species. In general, temporal changes of patterns and structure in the variability of soil properties or parameters have not been addressed on paddy soils (Roel and Plant, 2004).

Soil management according to the spatial variability, also known as site-specific crop management, has attracted interest in Argentina (BRAGACHINI et al., 2002). The main factors that are driving the change of agriculture to site specific management include: (1) social concern regarding environmental problems such as ecosystem damage and water pollution due to large use of agro chemicals. (2) global demands for environmentally safe agriculture, (3) pressure to strengthen the value of agricultural products to compete in global markets, and (4) labor shortage due to a decreasing and aging rural population.

Site-specific crop management can be viewed as a cyclical process of within field data collection, data analysis and optimum decision making, variable rate application, and evaluation. The application of this technique is, however, strongly dependent upon field scale and profitability. Yield, crop growth status, and soil properties are necessary data inputs to the system. As in other crops, in typical rice fields, describing spatial variability of within-field properties is a fundamental first step toward determining the size of homogeneous zones and the inter-relationships between limiting factors, for the development of management strategies. Site variables in interest are soil properties, crop growth status, and crop yield.

Geostatistics, based on the theory of regionalized variables, is the primary tool of spatial variability analysis. The results obtained from a geostatistical analysis are dependent on a number of variables, such as sampling frequency and number, sampling spacing and accuracy, and analysis parameter selection (JOURNEL and HuijBregts, 1978; Webster and Oliver, 1990; Vieira et al., 1997). Proper interpretation of the semivariogram and selection of appropriate models are very important for the analysis process (VIEIRA, 2000). The calculated semivariograms can then be used to produce maps of the investigated property by kriging, an interpolation method that yields unbiased estimates with minimal estimation variance.

The objective of this work was to describe the spatial-temporal variability of $\mathrm{pH}$ and Eh in a rice paddy field typical for Corrientes, Argentina.

\section{MATERIAL AND METHODS}

\section{Experimental site, soil and sampling}

The study site was a paddy field with 5.1ha cropped with irrigated rice (Oryza sativa L.), situated in the province of Corrientes, Argentina. The climate is warm, subtropical and its main features are high temperatures and abundant rainfall the whole year round. According to the U.S. Soil taxonomy the soil is a Typic Plintacualf with silty loam texture with $4.8 \%$ clay, $67.0 \%$ silt and $28.2 \%$ sand. Before the lime addition the soil $\mathrm{pH}$ was 3.7 , the organic matter content was $2.14 \%$, 
the cationic exchange capacity was $21.7 \mathrm{cmol}_{\mathrm{c}} \mathrm{kg}^{-1}$ and the exchangeable aluminium was $3.4 \mathrm{cmol}_{\mathrm{c}} \mathrm{kg}^{-1}$.

The field was divided in three sub plots at which dolomitic lime additions were made at the rates of control (without lime addition), with $625 \mathrm{~kg} \mathrm{ha}^{-1}$ and with $1250 \mathrm{~kg} \mathrm{ha}^{-1}$. The dolomite amendment was applied two months before sowing.

The soil was sampled at three different times along the rice vegetative period. The first time soil was collected when sowing, just prior to flooding, thus in aerobic conditions. Later on, during anaerobiosis soil samples were taken in two successive periods, four and eight weeks after flooding (i. e. 28 and 56 days) following bunch formation and flowering, respectively. The soil was collected with an auger to a depth of $15 \mathrm{~cm}$.

In each of the three sub plots and on the three sampling dates, ninety-six soil samples were collected on a $11.9 \times 20 \mathrm{~m}$ grid as shown in figure 1 . The sampling scheme used was intended to provide sufficient numbers of data pairs over a wide range of distances, thus allowing identification of short and long range variations (VIEIRA, 2000).

Prior to soil laboratory analysis, all samples were air-dried and sieved (2-mm mesh). The soil $\mathrm{pH}$ and Eh were determined on each of the soil samples by routine methods (THOMAs, 1996; PATRICK et al., 1996).

\section{Statistical and Geostatistical Analysis}

Exploratory statistical analysis included examination of mean values, coefficients of variation, maximum and minimum values. Proximity to the normal distribution was judged on the basis of KolmogorovSmirnov test.

Geostatistical analysis is based on the assumption that measurements separated by small distances are more likely to be similar to each other than those farther apart (i.e. spatial autocorrelation exists). This assumption can be verified through examination of semivariograms for the attributes under investigation. The semivariogram is a statistical tool used to measure the between-sample autocorrelation. Thus, the first step of the geostatistical analysis was to calculate sample semivariograms. For each variable treatment and sampling data, a graph was obtained that showed the amount of variance between points as a function of distance. Models of spatial dependence between neighbouring data were fitted to the semivariogram using the traditional fitting-by-eye method and the cross-validation technique, according to recommendations by VIEIRA (2000). The kriging method

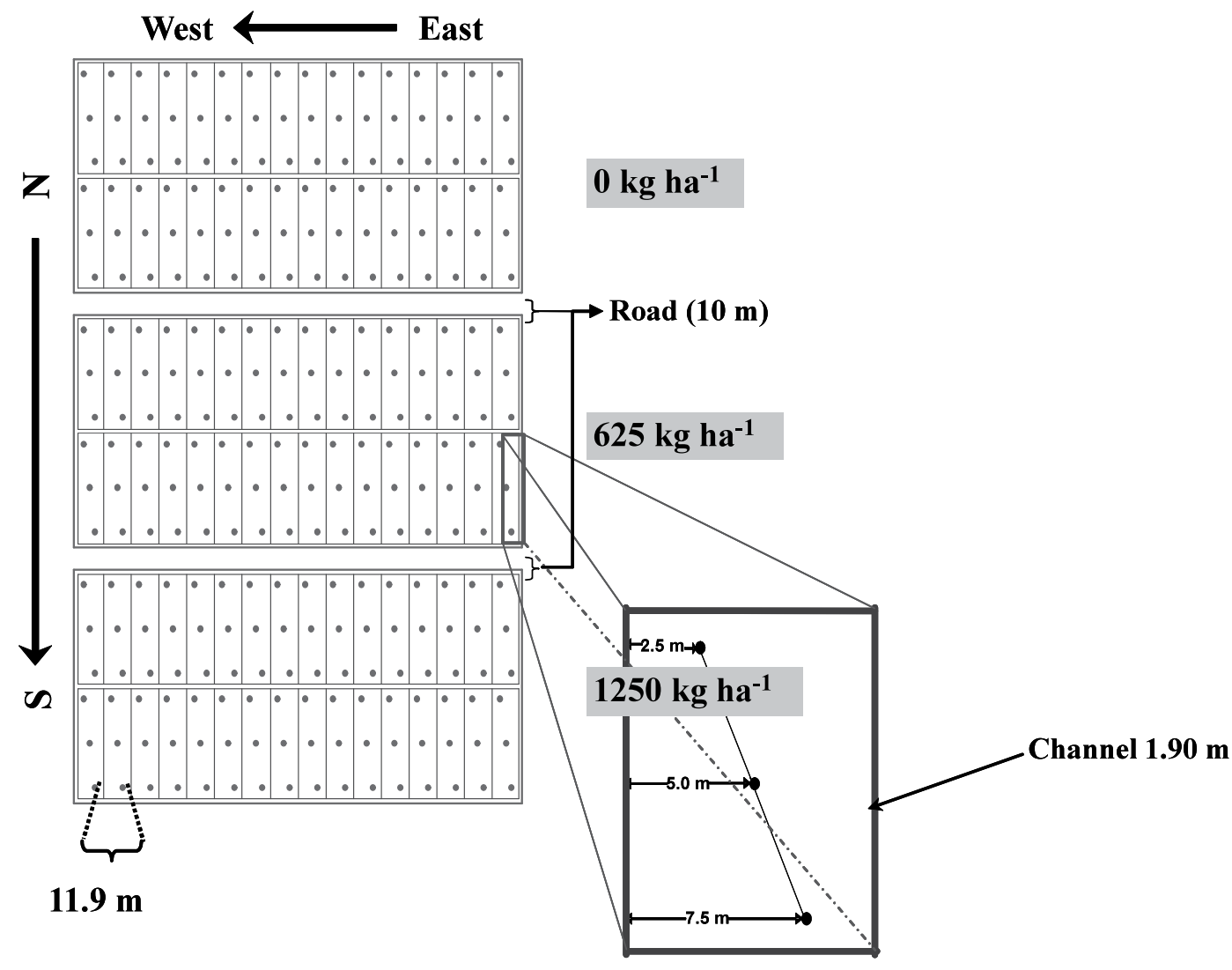

Figure 1. Sampling grid showing the 96 sampling points in each of the three treatments with different lime application rates. 
was used for interpolation at unsampled locations in order to construct contour maps for the expression of the spatial variability.

\section{RESULTS AND DISCUSSION}

Descriptive statistics for $\mathrm{pH}$ and Eh for the three lime treatments and three sampling dates are shown in table 1. Irrespective of lime application rate, the mean $\mathrm{pH}$ values increased after flooding, which is, generally, an expected result. The mean $\mathrm{pH}$ values ranged from 4.2 to 4.4 during the first sampling, 5.7 to 5.9 during the second sampling and 6.6 to 6.8 during the third sampling. Therefore, an increase of $\mathrm{pH}$ larger than two units was recorded along the rice growth period. The mean $\mathrm{pH}$ values were ranked on the inverse order of the lime application rate for the three sampling dates.

The mean Eh values decreased with time due to increased anaerobiosis. Mean Eh values ranked on the increasing order of the liming rate, contrasting with ranks for $\mathrm{pH}$. Mean Eh oscillated between 554.4 and $532.4 \mathrm{mV}$ during the first sampling, between -16.53 and $-30.13 \mathrm{mV}$ during the second sampling and between $-186,2$ and $-210,3$ during the third sampling. The continuous decrease of mean Eh values along the rice growth period, illustrate the large temporal variability of this parameter at this cultivation system (Figure 2).

The variability for $\mathrm{Eh}$ and $\mathrm{pH}$ data for a given treatment was rather important. The range of $\mathrm{pH}$ values within a plot was greater than 0.4 units at the first sampling date and even higher than 1 unit at the second and third sampling date. The range of Eh was between 40 and $75 \mathrm{mV}$ at the first sampling date and increased at the successive samplings with having an extreme high of $156 \mathrm{mV}$ for the third sampling with the $625 \mathrm{~kg} \cdot \mathrm{ha}^{-1}$ (Table 1).

Coefficients of variation (CV) for the first sampling were low (smaller than $2.1 \%$ ) for both $\mathrm{pH}$ and Eh. However, in anaerobic conditions, i.e. at the second and the third sampling, CV values were much higher for Eh than for $\mathrm{pH}$. Overall, $\mathrm{CV}$ ranged from $1.58 \%$ to $5.25 \%$ for $\mathrm{pH}$ and from $1.34 \%$ to $119.4 \%$ for Eh. Both $\mathrm{pH}$ and Eh exhibited the highest $\mathrm{CV}$ during the second sampling. Smaller coefficients of variation for $\mathrm{pH}$ than for other soil properties have been frequently reported for rainfed soils (VIEIRA and PAZ GONZÁLEZ, 2003) and paddy soils (TRANGMAR et al., 1987; YANAI et al., 2001; INAMURA et al., 2004).

The values of skewness were near 0 , i.e. in the range of 0.5 , in 12 out of 18 studied data sets, but frequency distributions were positive or negatively skewed in the other 6 data sets. Moreover kurtosis was generally close to 0 , so that 16 out 18 frequency distributions showed a platokurtic shape. These results suggest that frequency distributions for $\mathrm{pH}$ and Eh not always seem to be close to normal. However, the KolmogorovSmirnov tests showed that 17 out 18 data sets fitted a normal distribution, in spite of the more or less depart

Table 1. Summary statistics for Eh and $\mathrm{pH}$ at three sampling dates, and on three lime treatments. (Data for Eh in $\mathrm{mV}$ )

\begin{tabular}{|c|c|c|c|c|c|c|c|c|}
\hline & Treatment & Mean & Variance & C.V. & Minimum & Maximum & Skewness & Kurtosis \\
\hline \multicolumn{9}{|c|}{ First sampling } \\
\hline & control & 554.4 & 54.920 & 1.34 & 538.0 & 577.0 & 0.323 & 0.278 \\
\hline \multirow[t]{3}{*}{ Eh } & $625 \mathrm{~kg} \mathrm{ha}^{-1}$ & 539.7 & 111.400 & 1.96 & 507.0 & 568.0 & -0.182 & 0.959 \\
\hline & $1250 \mathrm{~kg} \mathrm{ha}^{-1}$ & 532.4 & 113.200 & 2.00 & 487.0 & 553.0 & -1.423 & 3.548 \\
\hline & control & 4.2 & 0.008 & 2.10 & 4.0 & 4.4 & 0.039 & -0.206 \\
\hline \multirow[t]{2}{*}{$\mathrm{pH}$} & $625 \mathrm{~kg} \mathrm{ha}^{-1}$ & 4.3 & 0.001 & 1.58 & 4.1 & 4.5 & 0.674 & 1.463 \\
\hline & $1250 \mathrm{~kg} \mathrm{ha}^{-1}$ & 4.4 & 0.010 & 1.68 & 4.3 & 4.7 & 1.349 & 3.231 \\
\hline \multicolumn{9}{|c|}{ Second sampling } \\
\hline \multirow{4}{*}{ Eh } & control & -16.5 & 389.600 & 119.40 & -76.0 & 25.0 & -0.570 & 0.464 \\
\hline & $625 \mathrm{~kg} \mathrm{ha}^{-1}$ & -25.8 & 240.100 & 60.00 & -69.0 & 19.0 & 0.136 & 0.007 \\
\hline & $1250 \mathrm{~kg} \mathrm{ha}^{-1}$ & -30.1 & 182.000 & 44.78 & -63.0 & -6.0 & -0.164 & -0.652 \\
\hline & control & 5.7 & 0.076 & 4.82 & 5.0 & 6.3 & -0.087 & -0.578 \\
\hline \multirow[t]{2}{*}{$\mathrm{pH}$} & $625 \mathrm{~kg} \mathrm{ha}^{-1}$ & 5.8 & 0.093 & 5.25 & 4.9 & 6.4 & -0.320 & 0.019 \\
\hline & $1250 \mathrm{~kg} \mathrm{ha}^{-1}$ & 5.9 & 0.059 & 4.11 & 5.3 & 6.5 & -0.062 & -0.209 \\
\hline \multicolumn{9}{|c|}{ Third sampling } \\
\hline \multirow{3}{*}{ Eh } & control & -186.2 & 1017.000 & 17.13 & -262.0 & -122.0 & -0.131 & -0.366 \\
\hline & $625 \mathrm{~kg} \mathrm{ha}^{-1}$ & -189.5 & 883.500 & 15.68 & -286.0 & -130.0 & -0.663 & 0.487 \\
\hline & $1250 \mathrm{~kg} \mathrm{ha}^{-1}$ & -210.3 & 965.800 & 14.78 & -275.0 & -146.0 & 0.023 & -0.739 \\
\hline \multirow{3}{*}{$\mathrm{pH}$} & control & 6.6 & 0.055 & 3.55 & 6.0 & 7.0 & -0.872 & -0.278 \\
\hline & $625 \mathrm{~kg} \mathrm{ha}^{-1}$ & 6.7 & 0.048 & 3.28 & 6.1 & 7.1 & -0.279 & 0.202 \\
\hline & $1250 \mathrm{~kg} \mathrm{ha}^{-1}$ & 6.8 & 0.015 & 1.77 & 6.5 & 7.1 & 0.119 & 0.159 \\
\hline
\end{tabular}




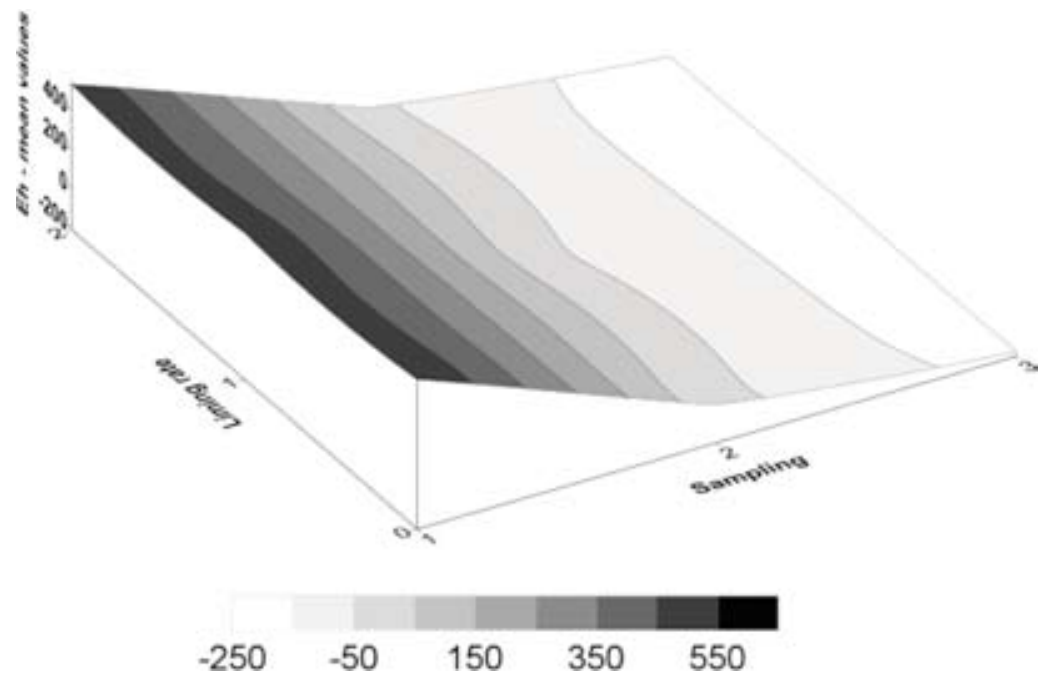

Figure 2. Temporal evolution of mean Eh values for the three lime application rates.

of skewness and kurtosis from standard values. The only exception was $\mathrm{pH}$ measured at the control plot during the third sampling. It is well established that, even though it is not required, kriging works better with normally distributed data (e. g. JouRnEL AND HuIJBREGTS, 1978; VIEIRA, 2000).

Figure 3 shows the experimental semivariograms for $\mathrm{pH}$ and $\mathrm{Eh}$ together with the respective fitted models for the control treatment. Model type, semivariogram parameters (sill, nugget and range) and parameters from cross validation (mean error, $\mathrm{ME}$, adimensional mean quadratic error, $\mathrm{AMQE}$ ) are summarised in table 2 .

All the experimental semivariogram display a steady increase in semivariance, with increasing lag distance, indicating a strong spatial dependence at small distance. A stable sill is reached suggesting there is no significant trend in all the 18 study data sets. All the $\mathrm{pH}$ and Eh experimental semivariograms were best fitted by spherical models with variable nugget effect, range of spatial dependence and sill values (Figure 3, Table 2).

In general, semivari ograms for $\mathrm{pH}$ and Eh could be fitted quite well, over the spatial scale of interest, by spherical models with a nugget component $\left(\mathrm{C}_{0}\right)$ plus a spatial component $\left(\mathrm{C}_{1}\right)$ with a range of spatial dependence between 44.9 and $77.5 \mathrm{~m}$ for all the 18 data sets. The nugget variances were all below $54 \%$ of the sill value, and in 13 out of 18 study cases below $30 \%$ of that value, which indicates, in general, good spatial continuity at close distances between sampled points.

The range of spatial dependence was from 44.9 to $66.6 \mathrm{~m}$ for $\mathrm{pH}$, whereas for Eh it was somewhat larger,

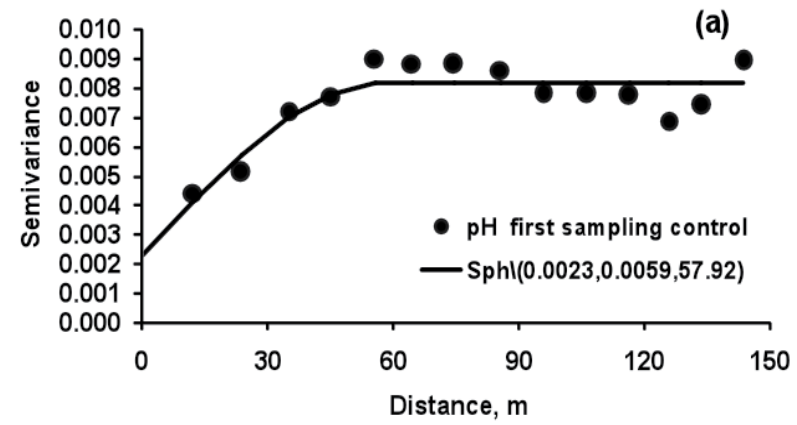

(b)

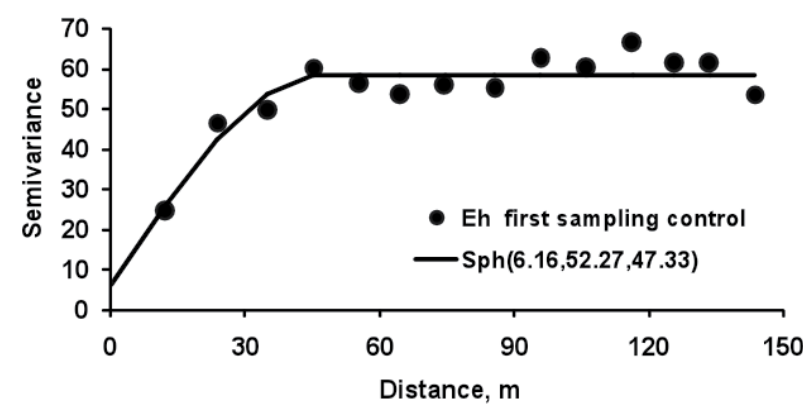

Figure 3. Experimental semivariograms and best fitted models for $\mathrm{pH}(\mathrm{a})$ and $\mathrm{Eh}(\mathrm{b})$ for the control treatment.

ranging from 47.3 to $77.5 \mathrm{~m}$. Following the criteria proposed by CAMBARDELla et al. (1994) the spatial dependence is considered strong when the ratio $\mathrm{C}_{0} /$ $\left(\mathrm{C}_{0}+\mathrm{C}_{1}\right)$ is lower $\tan 25 \%$ and moderate for values of this ratio between $25 \%$ and $75 \%$. It follows that $\mathrm{pH}$ exhibited a strong spatial dependence in 8 cases, whereas this dependence was moderate in 1 case. In contrast, the spatial dependence of Eh was strong for 3 data sets 
Table 2. Best fitted model parameters and cross-validation parameters for Eh and $\mathrm{pH}$ at three sampling dates, and on three lime treatments. $\left(\mathrm{C}_{0}=\right.$ nugget effect; $\mathrm{C}_{1}=$ sill; $\mathrm{a}=$ range; $\mathrm{r}^{2}=$ correlation coefficient; $\mathrm{ME}=$ Mean Error; $\mathrm{AMQE}=\mathrm{Adimensional}$ Mean Quadratic Error)

\begin{tabular}{|c|c|c|c|c|c|c|c|c|}
\hline & Treatment & Model & $\mathrm{C}_{0}$ & $\mathrm{C}_{1}$ & $\mathrm{a}(\mathrm{m})$ & $\mathrm{r}^{2}$ & $\mathrm{ME}$ & AMQE \\
\hline \multicolumn{9}{|c|}{ First sampling } \\
\hline & control & spherical & 6.16 & 52.27 & 47.33 & 0.878 & -0.0054 & 1.133 \\
\hline \multirow[t]{3}{*}{ Eh } & $625 \mathrm{~kg} \mathrm{ha}^{-1}$ & spherical & 19.56 & 93.51 & 56.40 & 0.892 & 0.0067 & 0.959 \\
\hline & $1250 \mathrm{~kg} \mathrm{ha}^{-1}$ & spherical & 9.28 & 113.75 & 68.31 & 0.888 & -0.0022 & 1.246 \\
\hline & control & spherical & 0.0023 & 0.0059 & 57.92 & 0.784 & 0.0173 & 0.839 \\
\hline \multirow[t]{2}{*}{$\mathrm{pH}$} & $625 \mathrm{~kg} \mathrm{ha}^{-1}$ & spherical & 0.00017 & 0.00463 & 57.92 & 0.885 & 0.0111 & 1.264 \\
\hline & $1250 \mathrm{~kg} \mathrm{ha}^{-1}$ & spherical & 0.00072 & 0.00504 & 59.10 & 0.903 & -0.0133 & 0.845 \\
\hline \multicolumn{9}{|c|}{ Second sampling } \\
\hline \multirow{3}{*}{ Eh } & control & spherical & 118.69 & 300.40 & 61.67 & 0.856 & 0.0027 & 0.694 \\
\hline & $625 \mathrm{~kg} \mathrm{ha}^{-1}$ & spherical & 117.23 & 136.97 & 63.28 & 0.916 & 0.0103 & 0.821 \\
\hline & $1250 \mathrm{~kg} \mathrm{ha}^{-1}$ & spherical & 101.46 & 86.74 & 66.11 & 0.851 & 0.0240 & 0.940 \\
\hline & control & spherical & 0.00372 & 0.0795 & 61.58 & 0.930 & -0.0151 & 1.107 \\
\hline \multirow[t]{2}{*}{$\mathrm{pH}$} & $625 \mathrm{~kg} \mathrm{ha}^{-1}$ & spherical & 0.00000 & 0.0974 & 44.93 & 0.869 & -0.0246 & 1.017 \\
\hline & $1250 \mathrm{~kg} \mathrm{ha}^{-1}$ & spherical & 0.028 & 0.031 & 51.76 & 0.661 & -0.0347 & 0.919 \\
\hline \multicolumn{9}{|c|}{ Third sampling } \\
\hline \multirow{4}{*}{ Eh } & control & spherical & 451.61 & 635.82 & 60.12 & 0.769 & -0.0021 & 0.759 \\
\hline & $625 \mathrm{~kg} \mathrm{ha}^{-1}$ & spherical & 245.73 & 745.43 & 76.63 & 0.892 & 0.0014 & 0.495 \\
\hline & $1250 \mathrm{~kg} \mathrm{ha}^{-1}$ & spherical & 458.80 & 584.95 & 77.48 & 0.858 & -0.0069 & 0.974 \\
\hline & control & spherical & 0.006 & 0.053 & 60.79 & 0.890 & 0.0009 & 1.008 \\
\hline \multirow[t]{2}{*}{$\mathrm{pH}$} & $625 \mathrm{~kg} \mathrm{ha}^{-1}$ & spherical & 0.002 & 0.048 & 45.51 & 0.793 & 0.0041 & 1.031 \\
\hline & $1250 \mathrm{~kg} \mathrm{ha}^{-1}$ & spherical & 0.003 & 0.012 & 45.84 & 0.938 & -0.0083 & 1.091 \\
\hline
\end{tabular}

and moderate for 6 data sets. Therefore, the imposed sampling grid captured large proportions of the spatial variance both for Eh and $\mathrm{pH}$, but it could be considered more adequate for characterising the spatial variability for $\mathrm{pH}$ than for Eh. Moreover, the grid density necessary to capture the spatial dependence changed with the lime treatment and also with the anaerobiosis state.

Spatial variability depends both on soil forming factors and management, which in paddy soils could be expected to be small because of approximately flat topography and the effects of flooding. Clearly climate, topography and water level are homogeneous on the experimental units. The parent material consisted of sedimentary rocks characterised by various particle size distributions, which could be a main cause of spatial variability.

Dynamics of $\mathrm{pH}$ and Eh is considered to be complex and it is affected by numerous internal factors or soil properties such as organic matter content, elemental composition or element speciation, which determine a number of chemical reactions and over a rice field are far from homogeneous. On the other hand, although all the experimental units were managed similarly, uneven water application due to inaccuracies of the flooding system and/or microrelief features could be also a source of spatial variability. Therefore, texture, soil mineral and organic composition, uneven flooding and microtopographic irregularities are possible factors influencing $\mathrm{pH}$ and Eh variability. It should be also emphasized that the lime distributions are assumed to be uniform within each treatment and therefore the treatments should have a limited effect on the spatial variability of $\mathrm{pH}$ and Eh.

Contour maps for $\mathrm{pH}$ and Eh made with values interpolated by kriging using the fitted semivariogram models are shown in figures 3 to 6 . All maps present discrete patches or small zones with distinct $\mathrm{pH}$ and Eh values. Patterns of spatial variation clearly show disparities between the three dolomite treatments for a given sampling date. Moreover, maps drawn for each liming treatment in successive dates also change, indicating a lack of temporal stability of $\mathrm{pH}$ and $\mathrm{Eh}$ at the studied plot scale.

In general $\mathrm{pH}$ contour maps show more patchiness than Eh maps. This trend is consistent with the somewhat higher nugget effect and larger range of Eh when compared with $\mathrm{pH}$.

The maps of $\mathrm{pH}$ obtained for the first sampling show distinct micro-regions with differences of about 0.4 units (Figure 4). In agreement with the statistical results, contour maps show the increase in $\mathrm{pH}$ spatial variability during the second sampling (Figure 5) as 
a)

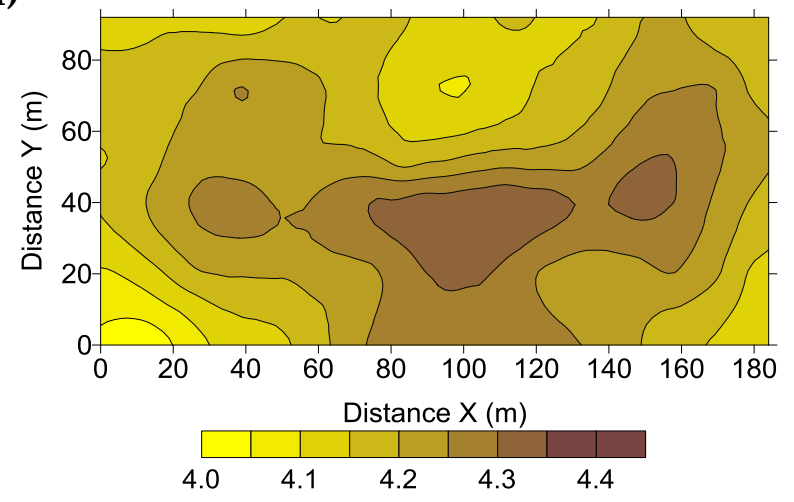

c)

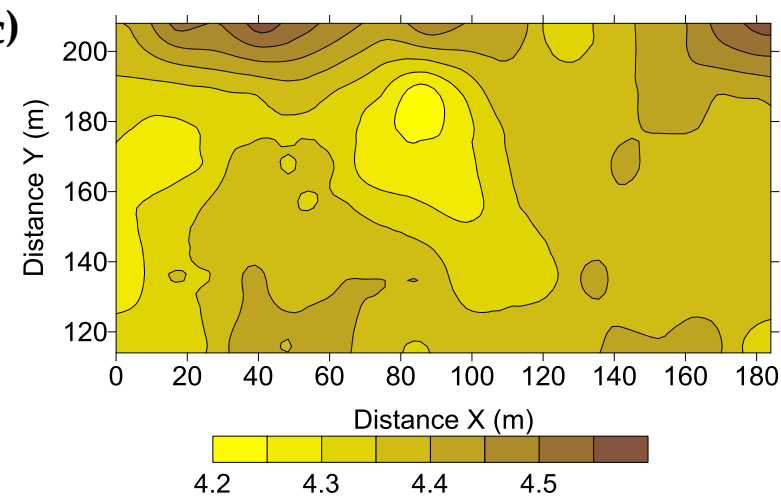

e)

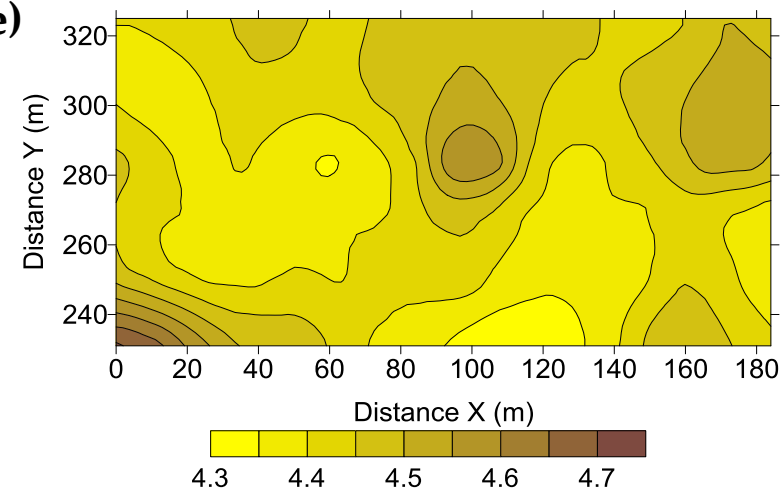

b)

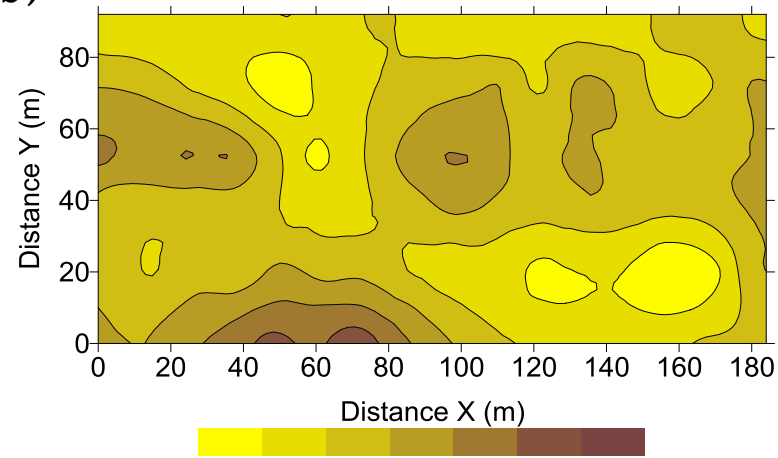

540546552558564570576


Figure 4. Contour maps of $\mathrm{pH}(\mathrm{a}, \mathrm{c}, \mathrm{e})$ and $\mathrm{Eh}(\mathrm{b}, \mathrm{d}, \mathrm{f})$ for different lime application rates during the first sampling date.

indicated by small areas with differences ranging from about 0.8 to 1.2 units. During the third sampling, $\mathrm{pH}$ differences of the small patches within a plot are in the range of about 0.5 to 1.0 units. When considering all the range of mapped data, $\mathrm{pH}$ values before flooding were between 4.0 and 4.8 , whereas after flooding they were between 6.1 and 7.1, with small differences regarding applied lime rate.
The range of Eh differences between patches of a given plot was of about 40 to $55 \mathrm{mV}$ during the first sampling, 55 to $75 \mathrm{mV}$ during the second sampling and 90 to $130 \mathrm{mV}$ during the third sampling. Notice that during the second sampling, at flowering, patches with maximum Eh values may be positive (treatments with 0 and $625 \mathrm{~kg} \mathrm{ha}^{-1}$ ), whereas those with minimum values are negative. Therefore at this stage aerobic and anaerobic areas are found on the same plot, which has consequences 
a)

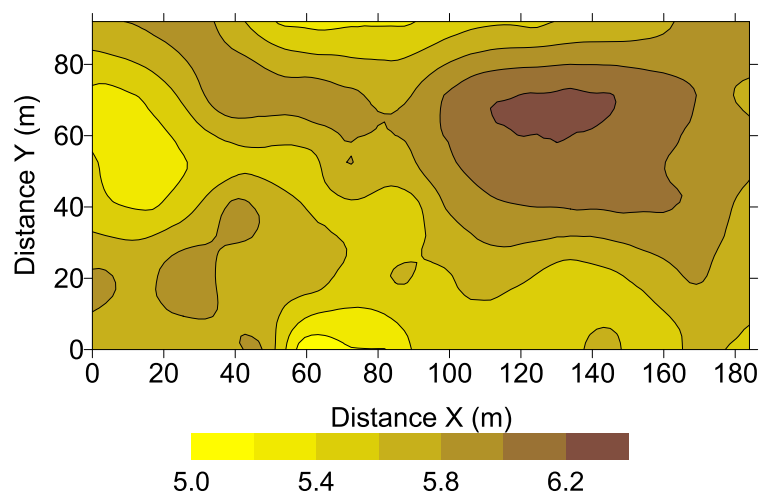

c)

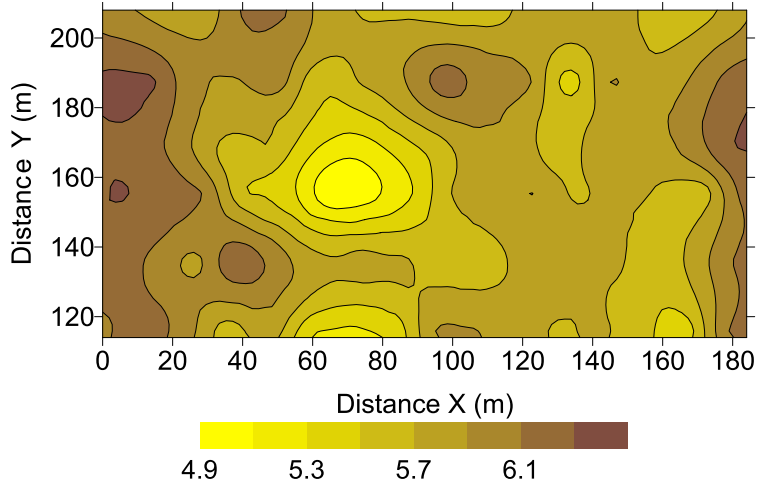

e)



b)



$\begin{array}{llllllll}-60 & -50 & -40 & -30 & -20 & -10 & 0 & 10\end{array}$
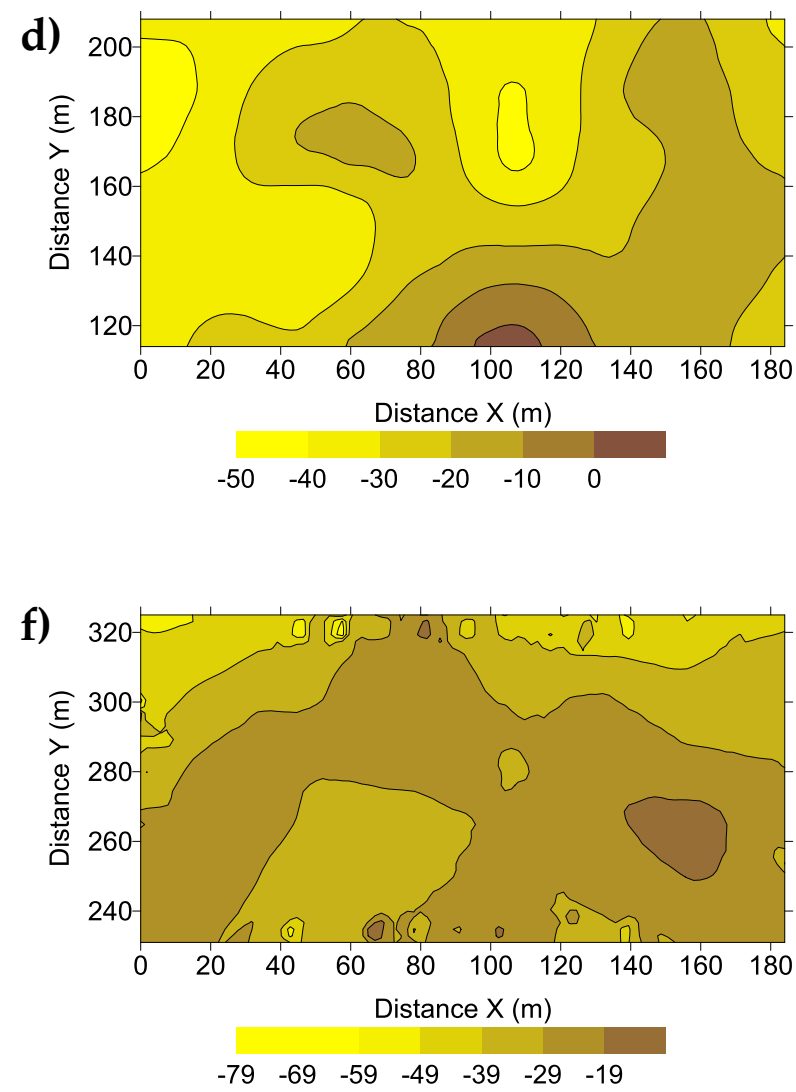

Figure 5. Contour maps of $\mathrm{pH}(\mathrm{a}, \mathrm{c}, \mathrm{e})$ and $\mathrm{Eh}(\mathrm{b}, \mathrm{d}, \mathrm{f})$ for different lime application rates during the second sampling date.

for rice development and production. This result indicates that variability in soil properties was not only present but was potentially of agronomic importance.

Contour maps also show that there is no correspondence between patches with maximum or minimum values of $\mathrm{pH}$ and $\mathrm{Eh}$. In some cases it can be observed that areas with maximum $\mathrm{pH}$ values showed a trend to match those with minimum Eh and vice versa. This is in accordance with the observed trend of even a small significant negative relationship between $\mathrm{pH}$ and $\mathrm{Eh}$.
Measurement and management of the small scale variability in rice fields raises both, challenges and opportunities for the causes of spatial variability. Small scale variability requires more careful consideration regarding both determination of design parameters and data processing issues. Precision agriculture strategies should be further investigated, depending on the feasibility of controlling spatiotemporal variability. The results presented show that there is a great potential to apply management strategies for rice production. 
a)

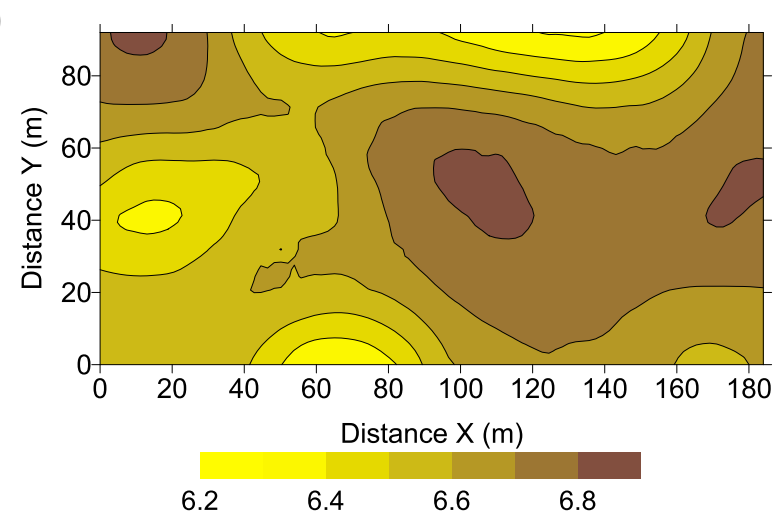

c)

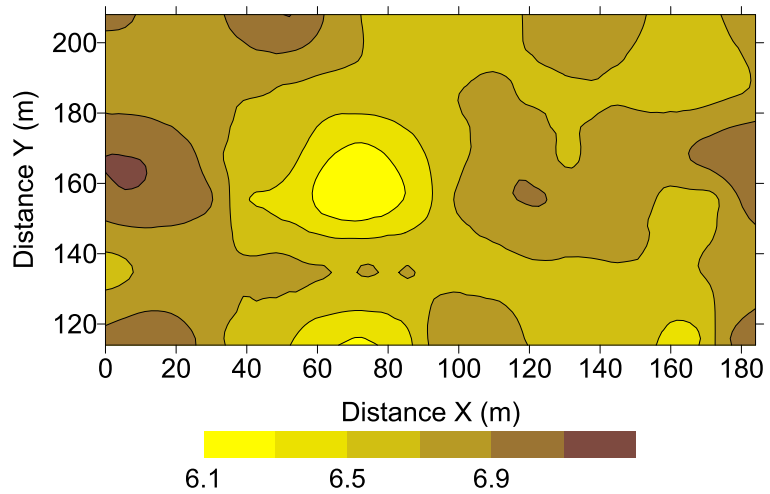

e)

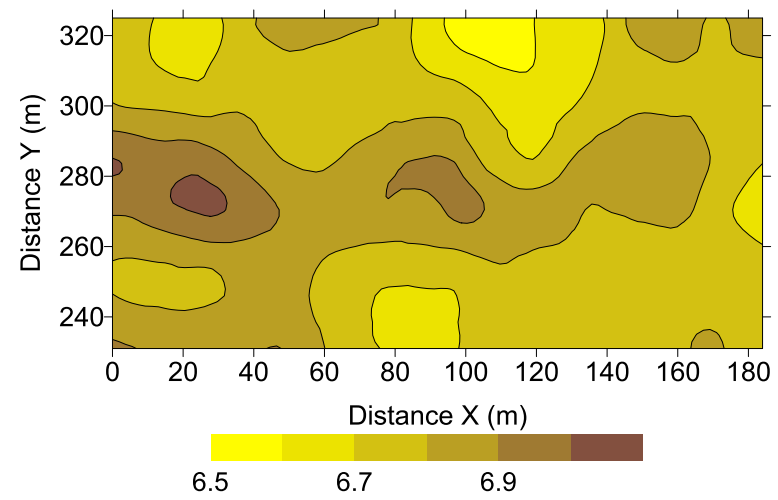

b)

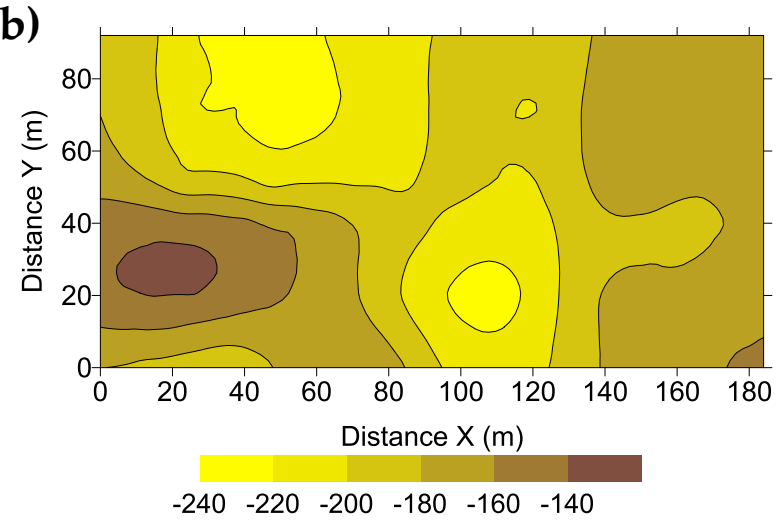

d)

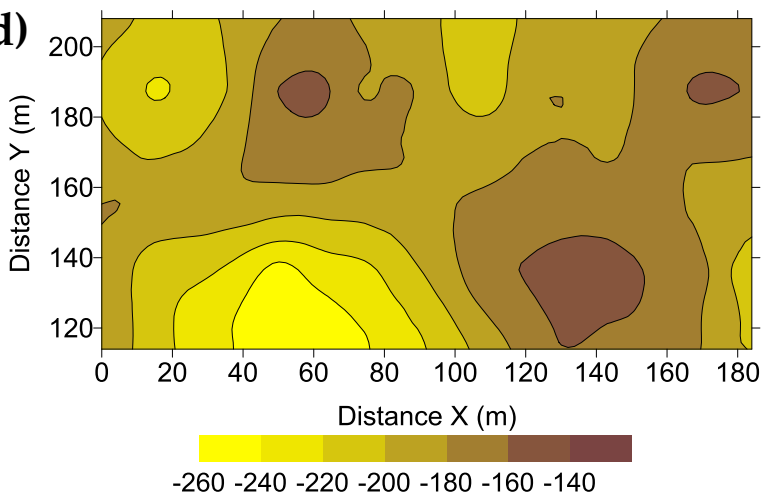

f)

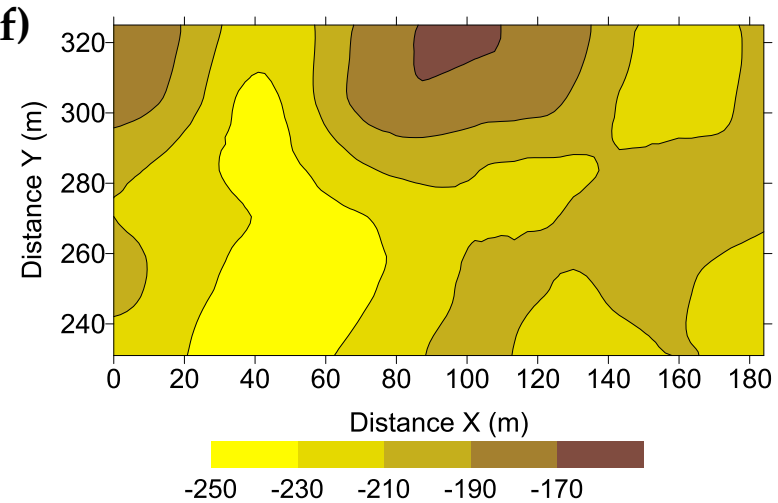

Figure 6. Contour maps of $\mathrm{pH}(\mathrm{a}, \mathrm{c}, \mathrm{e})$ and $\mathrm{Eh}(\mathrm{b}, \mathrm{d}, \mathrm{f})$ for different lime application during the third sampling date.

\section{CONCLUSIONS}

1. Spatial variability of $\mathrm{pH}$ and Eh on rice fields was far from negligible both on aerobic and on anaerobic conditions.

2. In general $\mathrm{pH}$ exhibited a stronger spatial dependence than Eh and also showed a tendency to present smaller ranges of spatial dependence.

3. Contour maps clearly showed the presence of small scale variability for $\mathrm{pH}$ and Eh within each liming treatment and during each of the three sampling dates.

4. Neither $\mathrm{pH}$ or Eh had temporal stability of the pattern of spatial distribution on field studied.

\section{REFERENCES}

BRAGACHINI, M.; von MARTINI, M.; MÉNDEZ, A.; BONGIOVANNI, R. Avances en la agricultura de precisión en Argentina. In: Tercer Taller Internacional de Agricultura de Precisión del Cono Sur de América. 7p, 2002. 
CAMBARDELLA, C.A.; MOORMAN, T.B.; NOVAK, J.M., PARKIN; T.B.; KARLEN, D.L.; TURCO, R.F.; KONOPKA, A.E. Field-scale variability of soil properties in central Iowa soils. Soil Science Society of America Journal, v.58, p.15011511, 1994.

CARÑEL, G.E. Censo productivo arrocero 2007-2008 Entre Rios. Resultados experimentales 2007-2008. PROARROZ. v. 17, p. 9-14, 2008.

IIDA, M., T. KAHO, T.; LEE, C. K.; UMEDA, M.; SUGURI, M. Measurement of grain yields in Japanese paddy field. p. 11651175. In P.C. Robert, R.H. Rust, and W.E. Larson (Ed.). Proc. 4th Intl. Conf. on Precision Agriculture. ASA, CSSA, and SSSA, Madison, pp.1165-1175. WI., 1999.

INAMURA, T.; GOTO, K.; IIDA, M.; NONAMI, K.; INOUE, H. and UMEDA, M. Goestatistical análisis of yield, soil properties and crop management practices in paddy rice filefs. Plant Production Science, v.7, p.230-239, 2004.

JOURNEL, A.G.; HUIJBREGTS, J. Mining Geostatistics. Academic Press: London, New York, San Francisco, 1978, 600 p.

PATRICK, JR., W.H.; GAMBRELL, R.P.; FAULKNER, S.P. Redox measurements of soils. In: SPARKS, D.L. (Ed.). Methods of Soil Analysis: Part 3-Chemical Methods. Madison, WI: 1996. p.12551276. Soil Science Society of America and American Society of Agronomy, (Soil Science Society of America Book Series 5)

PAZ GONZÁLEZ, A.; VIEIRA, S.R.; TABOADA CASTRO, M.T. The effect of cultivation on the spatial variability of selected properties of an umbric horizon. Geoderma, v.97, p.273-292, 2000.

ROEL, A.; PLANT, R.E. Spatiotemporal analysis of rice yield variability in two california fields. Agronomy Journal, v.96, p.77-90, 2004.
SUN, B.; ZHOU, S.; ZHAO, Q. Evaluation of spatial and temporal changes of soil quality based on geostatistical analysis in the hill region of subtropical China. Geoderma, v.115, p.85-99, 2003.

THOMAS, G.W. Soil pH and soil acidity. In: SPARKS, D.L. (Ed.). Methods of Soil Analysis: Part 3-Chemical Methods. Madison, WI: 1996. p.475-490. Soil Science Society of America and American Society of Agronomy, (Soil Science Society of America Book Series 5)

TRANGMAR, B.B.; YOST, R.S.; WADE, M.K.; UEHARA, G. and SUDJADI, M. Spatial Variation of Soil Properties and Rice Yield on Recently Cleared Land. Soil Science Society of America Journal, v.51, p.668-674, 1987.

VIEIRA, S.R. Geoestatística em estudos de variabilidade espacial do solo. In: NOVAIS, R.F., ALVAREZ, V.H., SCHAEFER, G.R. (Ed.). Tópicos em Ciência do Solo. Viçosa: Sociedade Brasileira de Ciência do Solo, 2000, v.1, p.1-54.

VIEIRA, S.R.; NIELSEN, D.R.; BIGGAR, J.W.; TILLOTSON, P.H. The scaling of semivariograms and the kriging estimation. Revista Brasileira de Ciência do Solo, v. 21, p.523-533, 1997.

VIEIRA, S.R.; PAZ GONZÁLEZ, A. Analysis of the spatial variability of crop yield and soil properties in small agricultural plots. Bragantia, v.62, p.127-138, 2003.

WEBSTER, R.; OLIVER, M.A. Statistical Methods in Soil and Land Resource Survey. Oxford: Oxford University Press, 1990, 316p.

YANAI, J.; CHOUNG, K.L.; KAHO, T.; IIDA, M.; MATSUI, T.; UMEDA, M. and KOSAKI, T. Geostatistical analysis of soil chemical properties and rice yield in a paddy field and application to the analysis of yield-determining factors. Soil Science and Plant Nutrition, v.47, p.291-391, 2001. 